\title{
Assessment tool to understand the readiness of Batik SMEs for Green Industry
}

\author{
Sylvia D A Kusumawardani ${ }^{1}$, Sunardi ${ }^{1,2}, T b$ Benito A Kurnani ${ }^{1}$ \\ ${ }^{1}$ Environment Science Program, Postgraduate School, Universitas Padjadjaran, Indonesia \\ ${ }^{2}$ Department of Biology, Faculty of Mathematics and Natural Science, Universitas Padjadjaran, Indonesia
}

\begin{abstract}
Batik industries in general are classified as Small Medium Enterprises (SMEs) with major problems related to environmental management and inefficiency of resource consumption. These problems cannot be solved by end of pipe approaches, instead, management since the upstream of the production process needs to be employed. The green industry is a concept that relevant to those problems since this prioritizes efficient resource use. The Indonesian government has developed the Green Industry Standard as a tool to assess the soundness of the industries and to promote the capability to compete in the global market. Globally, there are several concepts similar to the green industry, for example, eco-innovation and resource efficient and cleaner production (RECP) that have their own assessment tools to measure the readiness of the industries. This study aims to elaborate aspects in Green Industry Standard with other assessment tools to understand the readiness of Batik industries through Ministry of Industry Regulation Number 39 of 2019 regarding Green Industry Standard for Batik Industries. Finally, the new assessment tool was developed consisting of four major aspects, namely company characterization, description of the business model, analysis input and output, and readiness area. Each aspect included some criteria and required relevant data that need to be collected for assessment of the readiness of Batik SMEs in future research.
\end{abstract}

\section{Introduction}

Batik is known to the world as a symbol of Indonesian culture, especially since UNESCO recognized batik as a Masterpiece of Oral and Intangible Heritage of Humanity in 2009. There are several types and motifs of traditional batik which have philosophies according to their regional cultures [1]. Batik is also considered to have eco-friendly values, due to the efforts of traditional development from arts and crafts that lead to environmentally friendly and sustainable activities [2]. However, on the other hand, batik still faces considerable environmental problems, such as related to waste management.

Wastewater is one of the most common problems when discussing the production process of batik. Nearly $85 \%$ of clean water consumption becomes wastewater with a large volume, dark color, and strong odor [2]. In general, batik wastewater is discharged directly into absorption wells or other water bodies without proper treatment, so it potentially pollutes the water environment nearby [3]. This happened to the batik industry in Kulon Progo, which received complaints from residents due to changes in the quality of well water which also became muddy, smelly, and itchy. This condition has been felt by nearby residents since about 4-5 years ago [4].

The dependence of the batik industry on kerosene fuel and electricity consumption has made the batik industry contribute to greenhouse gas emissions. This industry is predicted of having the highest annual $\mathrm{CO}_{2}$ emissions among other SMEs [1]. In addition to greenhouse gas emissions, the batik industry also produces air emissions that contain particulates or gases such as $\mathrm{NO}_{2}, \mathrm{CO}_{2}$, and $\mathrm{SO}_{\mathrm{x}}$ [5]. Batik industry still uses traditional and very simple technology, which could be one of the major problem sources because it generates waste from the inefficiency of the production process. This inefficiency causes a large volume of waste generated from raw materials, additives materials, and production processes [6].

According to the problems that arise, it is difficult to rely solely on the end of pipe environmental management. It must be done from the upstream of the production process by increasing the efficiency and effectiveness of resource consumption. This is in line with the principles of the green industry, that is defined in Act Number 3 of 2014 regarding Industrialization as any Industry with a production process which places a priority on efficiency and effectiveness in the sustainable use of resources, to enable harmonization between Industrial development and the preservation of environmental functions as well as to grant benefits to the community. To assess the implementation of the green industry, the Indonesian government creates a tool that can be used by industry as a reference for its production process, called the Green Industry Standard. This standard consists of the limitation of resource consumption and waste generation, as well as company management that must be carried out. For the batik industry, this standard is stipulated in Minister of 
Industry Regulation Number 39 of 2019 regarding the Green Industry Standard for the Batik Industry.

Besides production process stages and environmental management, SMEs' readiness to change is a key consideration to implement the changes advocated in environmental sustainability programs [7]. Green Industry Standard could be one of the tools to assess the readiness of SMEs. In addition, several concepts have a similar definition with the green industry, such as eco-innovation and Resource Efficient and Cleaner Production (RECP), which has their assessment tool to measure the readiness of SMEs. This study aims to elaborate aspects in Green Industry Standard with other assessment tools to understand the readiness of Batik industries for Green Industry. The new assessment tool will be developed through this study, and it can be used for further research.

\section{Material and methods}

This study conducted a qualitative comparison using the head to head approach. There are three main sources, namely:

1. Green industry standard for Batik industries which developed by the Ministry of Industry (2019)

2. Eco-innovation screening tools which developed by Pigosso et al. (2018), and

3. RECP indicators for SMEs which developed by UNIDO and UNEP (2010)

The comparison was based on two major key points, the definition and the assessed aspects of each source. Furthermore, the aspects in the Green Industry Standard were elaborated with aspects in eco-innovation screening tools and RECP indicators.

\subsection{Green Industry Standard}

According to Act Number 3 of 2014 regarding Industrialization, the green industry defines as any Industry with a production process which places a priority on efficiency and effectiveness in the sustainable use of resources, to enable harmonization between Industrial development and the preservation of environmental functions as well as to grant benefits to the community. Completing that regulation, the Ministry of Industry established a tool to assess the production process of industries whether efficient and effective or not, called the Green Industry Standard. This standard consists of technical requirements as well as managerial requirements. The technical requirements determine resource use limitations, such as material, energy, and water. Moreover, it specifies waste management, product quality, and product packaging. Green Industry Standard for Batik Industries is regulated in the Minister of Industry Regulation Number 39 of 2019. The aspects in technical requirement consist of (1) Raw material; (2) Auxiliary material; (3) Energy; (4) Water; (5) Product; (6) Packaging; (7) Waste; (8) Greenhouse Gasses.

\subsection{Eco-Innovation Screening Tools}

According to the Eco-innovation action plan by Commission of the European Communities (2001), ecoinnovation is defined as "any form of innovation resulting in or aiming at significant and demonstrable progress towards the goal of sustainable development, through reducing impacts on the environment, enhancing resilience to environmental pressures, or achieving a more efficient and responsible use of natural resources". Furthermore, United Nations Environmental Programme (UNEP) defined eco-innovation as "the development and application of a business model, shaped by a new business strategy that incorporates sustainability throughout all business operations based on life cycle thinking and in cooperation with partners across the value chain". This screening tool has been developed in the Danish project "Residue to Resource" which was conducted in collaboration between the Danish Symbiosis Centre, the Technical University of Denmark, and six municipalities. This tool also has been implemented to 108 SMEs from various sectors, including service industries, distributed in six municipalities. Through this study, the screening tool has been determined with four major aspects, namely (1) Company characterization; (2) Description of the business model; (3) Analysis of input and output flows, and (4) Readiness areas [8].

\subsection{RECP Indicators}

RECP for SMEs is introduced by United Nations Industrial Development Organization (UNIDO) and United Nations Environmental Programme (UNEP) through their publication "Enterprise-level Indicators for Resource Productivity and Pollution Intensity: A Primer for Small and Medium-Sized Enterprises" (2010). In this publication, RECP is defined as "a preventive, enterprise-level approach to improving resource use, reducing environmental pollution and contributing to sustainable industrial development based on the continuous application of an integrated preventive environmental strategy to processes, products, and services in order to increase overall efficiency and to reduce risks to humans and the environment" [9]. The indicators system that is developed by UNIDO and UNEP consists of six absolute indicators, three relates to resource use, and three relates to pollution, and one reference-indicator. Indicators relate to resource use are energy use, material use, and water use. On the other hand, indicators relate to pollution are air emissions, wastewater, and waste. The reference indicator or absolute production indicator covers the product output or value created by the enterprise.

\section{Result and discussion}

This section has presented the result and discussed the comparative analysis using a head to head approach from three kinds of literature. The result and discussion 
are divided into two major key points, the definition and the assessed aspects.

\subsection{Comparison of the definitions}

From the brief explanation in the previous section, the definitions of the green industry, eco-innovation, and RECP are presented in Table 1.

Table 1. Definition Comparison

\begin{tabular}{|c|c|c|}
\hline Green Industry ${ }^{1}$ & Eco-innovation $^{2}$ & RECP $^{3}$ \\
\hline $\begin{array}{l}\text { Any Industry with a } \\
\text { production process } \\
\text { which places a priority } \\
\text { on efficiency and } \\
\text { effectiveness in the } \\
\text { sustainable use of } \\
\text { resources, to enable } \\
\text { harmonization between } \\
\text { Industrial development } \\
\text { and the preservation of } \\
\text { environmental functions } \\
\text { as well as to grant } \\
\text { benefits to the } \\
\text { community. }\end{array}$ & $\begin{array}{l}\text { Any form of innovation } \\
\text { resulting in or aiming at } \\
\text { significant and demonstrable } \\
\text { progress towards the goal of } \\
\text { sustainable development, } \\
\text { through reducing impacts on the } \\
\text { environment, enhancing } \\
\text { resilience to environmental } \\
\text { pressures, or achieving more } \\
\text { efficient and responsible use of } \\
\text { natural resources (Eco- } \\
\text { innovation Action Plan, 2001). } \\
\text { UNEP defined eco-innovation } \\
\text { as the development and } \\
\text { application of a business model, } \\
\text { shaped by a new business } \\
\text { strategy that incorporates } \\
\text { sustainability throughout all } \\
\text { business operations based on } \\
\text { life cycle thinking and in } \\
\text { cooperation with partners across } \\
\text { the value chain (UNEP. 2017). }\end{array}$ & $\begin{array}{lr}\text { A preventive, enterprise- } \\
\text { level approach to } \\
\text { improving resource use, } \\
\text { reducing environmental } \\
\text { pollution, r and } \\
\text { contributing r to } \\
\text { sustainable industrial } \\
\text { development. }\end{array}$ \\
\hline
\end{tabular}

Source: ${ }^{1}$ Act Number 3 of 2014 regarding Industrialization; ${ }^{2}$ Pigosso et al. (2018); ${ }^{3}$ UNIDO and UNEP (2010)

In general, those three concepts have a similar definition, which is related to the efficiency of resource consumption. However, eco-innovation had broadened its definition to business model innovation. It was a great movement because business model innovation has a significant impact on competitive advantage and SME financial performance [10].

\subsection{Comparison of the assessed aspects}

Those three concepts have their assessment tool. The green industry has the standard that can be applied by industries, while eco-innovation has the screening tool to understand the readiness of the industries. RECP has a simpler tool to assess the industries through their RECP indicators. The details of each tool are present in Table 2.

Table 2. Assessed Aspects Comparison

\begin{tabular}{lllll}
\hline Green Industry Standard $^{1}$ & \multicolumn{2}{l}{ Eco-innovation Screening Tool $^{2}$} & RECP Indicators $^{3}$ \\
\hline 1. & Raw Material & $\begin{array}{l}\text { Block 1: Company } \\
\text { Characterization }\end{array}$ & 1. Energy use \\
2. Complementary Material & $\begin{array}{l}\text { Block 2: Description of the } \\
\text { Business Model }\end{array}$ & 2. Materials use \\
Block 3: Analysis of Input \& & 3. Water use \\
3. Energy & $\begin{array}{l}\text { Output Flows } \\
\text { Sub Block 3.1: Preliminary }\end{array}$ & 4. Air emissions \\
4. Water & $\begin{array}{l}\text { Assessment } \\
\text { Sub Block 3.2: Mapping 5. Wastewater }\end{array}$ \\
5. Product & $\begin{array}{l}\text { Energy Streams } \\
\text { Sub Block 3.3: Mapping 6. Waste }\end{array}$ \\
6. Packaging & $\begin{array}{l}\text { Water Streams } \\
\text { Sub Block 3.4: Mapping }\end{array}$ \\
7. Waste & $\begin{array}{l}\text { Material Streams } \\
\text { 8. Greenhouse gasses }\end{array}$ \\
\hline
\end{tabular}

Source: ${ }^{1}$ Minister of Industry Regulation Number 39 of 2019 regarding Green Industry Standard for Batik Industries; ${ }^{2}$ Pigosso et al. (2018); ${ }^{3}$ UNIDO and UNEP (2010)

The Green Industry Standard is classified based on eight aspects; with each aspect has its own criteria. Meanwhile, eco-innovation has a more complex aspect consisting of four main blocks with each required data. On the other hand, RECP has a simpler indicator that only consists of six absolute indicators which are divided based on two approaches.

From the assessed aspects in each concept, it can be seen that eco-innovation has the most aspects. This is because the scope of the eco-innovation screening tool has expanded to the area of business model innovation and also specifically assesses the readiness of the industry to be involved in eco-innovation development projects. However, when compared to Green Industry Standards and RECP Indicators, several aspects have not been included in the screening tool, especially related to products, packaging, and air emissions.

Definition and classification of SMEs are often based on the number of employees, industry classification, or the turnover of an organization [11]. According to the Organization for Economic Cooperation and Development (OECD, 2005) in Jabbour et al. (2019), "SMEs are non-subsidiary independent enterprises, where the salient features are the number of employees and extent of financial assets". Cameron et al. (1999) in Seidel-Sterzik et al. (2018) defines SMEs without referring to the number of employees, it states "A small business can be defined as a business that is independently managed by the owners, who own most of the shares, provide most of the finance and make most of the principal decisions."

Seidel-Sterzik et al. (2018) conclude from several kinds of literature eight barriers faced by SMEs which is closely related to the specific characterization of SMEs. Those are (1) owner/manager influence and structure; (2) environmental culture; (3) resource availability; (4) strategy; (5) knowledge of environmental issues; (6) market requirements; (7) geographical separation of production and consumption; and (8) communication and information sharing. Batik SMEs are also facing this problem, especially related to human management and resource consumption. The significant potential for improving resource efficiency in manufacturing companies range from $10-40 \%$ of possible savings which can be achieved even with available technology [12]. Therefore, it is important to address those problems in the assessment tool. The new assessment tool is developed by synthesizing the three assessment tools, with main aspects refer to the ecoinnovation screening tool that has the most assessed aspects.

Table 3. Aspects in eco-innovation screening tool linked with the barriers

\begin{tabular}{|c|c|}
\hline Aspects in screening tool & Barriers \\
\hline Block 1: Company Characterization & $\begin{array}{l}\text { owner/manager influence and structure; } \\
\text { strategy; }\end{array}$ \\
\hline Block 2: Description of the Business Model & $\begin{array}{l}\text { owner/manager influence and structure; } \\
\text { strategy; knowledge of environmental } \\
\text { issues; market requirements; } \\
\text { communication and information sharing }\end{array}$ \\
\hline Block 3: Analysis of Input \& Output Flows & $\begin{array}{l}\text { environmental culture; resource availability; } \\
\text { knowledge of environmental issues; market } \\
\text { requirements; geographical separation of } \\
\text { production and consumption }\end{array}$ \\
\hline Block 4: Readiness Area & $\begin{array}{l}\text { owner/manager influence and structure; } \\
\text { strategy; knowledge of environmental } \\
\text { issues; market requirements; } \\
\text { communication and information sharing }\end{array}$ \\
\hline
\end{tabular}

\section{Conclusion}

In this paper, an assessment tool to understand the readiness of Batik SMEs was developed and presented. 
Green industry standard as a basic tool for the assessment was synthesized with other tools, such as eco-innovation screening tool and RECP indicators. Through the result and discussion section, it is shown that the eco-innovation screening tool has more assessed aspects than other tools. In addition, this tool not only focused on the production process but also the business model. Besides, this tool could address the main barriers that are faced by SMEs. Therefore the new assessment tool was developed using four main blocks from the ecoinnovation screening tool, with the specific criteria for each block was the result of synthesizing those three tools.

\section{References}

1. Jusri \& M. Idris, Batik Indonesia: Soko Guru Budaya Bangsa, Ditjen IKM Kementerian perindustrian, Jakarta (2012)

2. L. Indrayani, Pengolahan Limbah Cair Industri Batik sebagai Salah Satu Percontohan IPAL Batik di Yogyakarta, Ecotrophic. 12. 2, 173-184 (2018)

3. Y. W. Ratih, P. B. Santosa, E. Muryani, Pengaruh Limbah Industri Batik menggunakan Pewarna Alami dari Desa Wukirsari terhadap Viabilitas Bakteri Tanah, Eksergi. XIII. 2, 7-13 (2016)

4. T. Wiryatmoko, Dampak Limbah Industri Batik, Sumur Warga Keruh dan Berbau, Retrieved Agustus 12, 2020, from Jogjadaily: https://jogjadaily.com/2020/01/dampak-limbahindustri-batik-sumur-warga-keruh-dan-berbau/, (2020)

5. L. Indrayani, Perhitungan Potensi Emisi Gas Rumah Kaca dari Sektor Industri Batik berdasarkan Metode IPCC Guidelines (2006), Envirotek. 11. 1 (2019)

6. D. I. Rinawati, D. P. Sari, S. Nugroho, F. Muljadi, S. P. Lestari, Pengelolaan Produksi menggunakan Pendekatan Lean and Green untuk menuju Industri Batik yang Berkelanjutan (Studi Kasus di UKM Puspa Kencana), J@TI Undip. VIII. 1, 4350 (2013)

7. J. Redmond, J. W. Cox, A. Kirk-Brown, B. Walker, Beyond business as usual: how (and why) the habit discontinuity hypothesis can inform SME engagement in environmental sustainability practices, Aus J of Env Man. 23. 4, 426-442 (2016)

8. D. C. Pigosso, A Schmiegelow, M. M. Andersen, Measuring the Readiness of SMEs for EcoInnovation and Industrial Symbiosis: Development of a Screening Tool, Sustainability (2018)

9. UNIDO, UNEP, Enterprise-Level Indicators for Resource Productivity and Pollution Intensity: A Primer for Small and Medium-Sized Enterprises, UNIDO, Vienna (2010)

10. M. Anwar, Business Model Innovation and SMES Performance - Does Competitive Advantage Mediate? Int J of Inno Man (2018)
11. H. Seidel-Sterzik, S. McLaren, E. Garnevska, Effective life cycle management in SMEs: use of a sector-based approach to overcome barriers, Sustainability (2018)

12. S. Thiede, G. Bogdanski, C. Herrmann, $A$ systematic method for increasing the energy and resource efficiency in manufacturing companies, Procedia CIRP 2, 28-33 (2012) 